Ian Douglas Wilson

\title{
Joseph, Jehoiachin, and Cyrus: On Book Endings, Exoduses and Exiles, and Yehudite/Judean Social Remembering
}

Ian Douglas Wilson: University of Alberta; iwilson@ualberta.ca

In a recent article in ZAW, ${ }^{1}$ Michael Chan cogently argues three points concerning the conclusion to the book of Kings (II Reg 25,27-30): (1) the conclusion alludes to the Joseph story, especially Gen $40-41 ;^{2}$ (2) this allusion supports recent hypotheses of an Enneateuchal redaction, sometime in the early Second Temple era, which linked together Hexateuchal material and material that now constitutes the books of Judges and Samuel-Kings; ${ }^{3}$ and (3) this allusion provides a hermeneutical key for understanding the purpose of the conclusion in this context, that is, it points to an imminent exodus, a return from exile and a gathering of diaspora in the promised land. In this article, I want to flesh out some of the implications of Chan's final point. If Chan is correct to point us in this direction, which I think he is, then his suggestion raises a number of interesting questions concerning the social memory of Yehudites/Judeans ${ }^{4}$ in the early Second Temple period.

Chan writes, »the allusive bridge that is built to the Joseph story brings to mind the broader history of the people of Israel - Jacob's family - with which the Hexateuch is primarily concerned (Gen+Ex-Jos). Both the family of Jacob at the end of Genesis and Jehoiachin find themselves in similar situations - enjoying the benevolence and bounty of a foreign ruler. $\aleph^{5}$ He states moreover, »hope lies in the fact that the Book of Kings ends as Genesis does - with some of Israel in Egypt and with an impending new exodus that is signaled by the benevolent treatment of Jehoiachin. ... The Book of Kings achieves its denouement on a note of hope that, at some point in the future, Israel would again experience a second

1 M. J. Chan, Joseph and Jehoiachin: On the Edge of Exodus, ZAW 125 (2013), 566-577.

2 Cf. J.E. Harvey, Jehoiachin and Joseph, in: R. Heskett/B. Irwin (eds.), The Bible as a Human Witness to Divine Revelation, LHBOTS 469, 2010, 51-61.

3 E.g., inter alia, R. G. Kratz, The Composition of the Narrative Books of the Old Testament, 2005, 216-221.321; K. Schmid, The Old Testament: A Literary History, 2012, 160-162.

4 Hereafter, Yehudites.

5 Chan, Joseph, 574. 
exodus and a new opportunity to live in the land. $\varkappa^{6}$ Chan argues that, for the tradents of these books, this moment in Judah's past was not seen as the end of an era, but was understood to be the beginning of a new one. Picking up where Chan left off, I ask: How, then, did the literate community in Yehud - who were reading and contemplating this text as one part of an emerging corpus of authoritative Yehudite literature - construe this era in its recent past? What did it mean for early Second Tempe-era literati to remember Joseph's life in Egypt as presaging Jehoiachin's in Babylon, and thus to remember Jehoiachin as a precursor to another exodus from a foreign land and another eisodus to the land of Israel? And what does this tell us about how this group saw its past, present, and future in the land? In the quote above, Chan's qualifying phrase »at some point in the future» is not insignificant. The narrative from Joseph to Moses to Joshua is considerable; its plot is complex and its import for Israel's larger story is multifaceted. If the literati indeed constructed an allusive bridge between Joseph and Jehoiachin, and if, in turn, the narrative found in Exodus-Joshua framed and shaped their memories of the period from Jehoiachin to their present, then we should look to the many details and complexities of this narrative to further explicate the import of the Jehoiachin-Joseph allusion within Yehudite discourse. In other words, the allusion partly indicated a »hopeful future ${ }^{7}{ }^{7}$ but it also indicated much more.

The exodus - and all that happens before, during, and after it - is hopeful and disappointing, a cause for celebration and punishment. It is the era of Mosaic revelation, the source of Torah, which solidifies the people's special status while simultaneously forecasting its downfall; it lays out the possibilities for Israelite political structures in future eras, and yet hints at the inherent weaknesses of such structures. Exile, with its similar array of theological/ideological tropes, is exodus's inversion. Robert Carroll comments:

Exile and exodus: those are the two sides or faces of the myth that shapes the subtexts of the narratives and rhetoric of the Hebrew Bible. Between these twin topoi (and their mediating notion of the empty land) is framed, constructed and constituted the essential story of the Hebrew Bible. They reflect a deep narratological structure and constant concern with journeys into or out of territories. Of course, any journey out of the land or out of a country is equally a journey into a different land or country (it is a zero sum game). So exodus equals exile or deportation and vice versa. ${ }^{8}$

6 Chan, Joseph, 575.

7 Chan, Joseph, 576.

8 R.P. Carroll, Exile! What Exile? Deportation and the Discourses of Diaspora, in: L. Grabbe (ed.), Leading Captivity Captive, JSOTSup 278, 1998, 62-79, 63 (italics original). 
Thus, to infer exodus at the end of exile is to remember an entire complex of thought, one that pervades the ancient Yehudite texts that are now part of the Hebrew Bible. As Chan mentions at the end of his article, the conclusion to Kings took part in a discourse that included other authoritative texts such as Chronicles and the prophetic books. ${ }^{9}$ The end of Kings, with a Davidic ruler in exile, looks back to the end of Genesis, and both books look forward to exodus, to a journey back to the promised land (itself a polyvalent concept); the end of Chronicles, with a quasi-Davidic ruler in Persia, looks back to the Davidic program of temple-building in Jerusalem, and looks forward to building a new temple there (cf. Ezr 1,1-4). And for each of these narratives (and others) one can find conversation partners in the prophetic books that further enrich the discourse. Below, I expand upon these comments in order to make several observations concerning these book endings and their functions in Yehudite social remembering. First, I consider some of the contours of the exodus story in Exodus-Joshua, and how these details might have informed memories of exile and return for those literati reading the book of Kings. Second, I take a look at the end of Chronicles and its presentation of a quasi-Davidic foreigner as Israel's new temple-builder. Finally,

9 A considerable number of scholars argue that the books of the Pentateuch; Joshua, Judges, Samuel, Kings (i.e., the »Former Prophets«); and the prophetic books (i.e., the »Latter Prophets«) took their authoritative forms in the early Second Temple period in Jerusalem/Yehud. One can add to this list a number of Psalms as well as the book of Chronicles (and perhaps Ezra-Nehemiah, depending upon how one dates these texts), since Chronicles too is typically considered to be a product of this era. Thus, these books (and probably a few others that are not relevant to this article) are literary artifacts from this period, and their discourses may serve as sources for our investigations of the literate community that produced, maintained, and read them. This is not to deny the long and complex compositional history of these texts; it is to focus on reconstructing how these books/scrolls functioned for the (surely small and tightly knit) community in which and by which they emerged as authoritative documents. For examples of scholarship that support this stance on the books' primary milieu (but with different approaches, aims, and outcomes), see L. Grabbe, The Law, the Prophets, and the Rest, DSD 13 (2006), 319-338; R. Achenbach, The Pentateuch, the Prophets, and the Torah in the Fifth and Fourth Centuries BCE, in: O. Lipschits/G. Knoppers/R. Albertz (eds.), Judah and the Judeans in the Fourth Century BCE, 2007, 253-285; E. Ben Zvi, Reconstructing the Intellectual Discourse of Ancient Yehud, SR 39 (2010), 7-23; D. M. Carr, The Formation of the Hebrew Bible, 2011, 204-224; D. Edelman, Introduction, in: D. Edelman (ed.), Deuteronomy-Kings as Emerging Authoritative Books, SBLANEM 6, 2014, 1-25. That said, I should also emphasize that this is not to say these books were completely stabilized by the early Second Temple period. The books remained fluid to a certain extent throughout antiquity, and in some cases may have circulated in different versions (cf. LXX Jer). Nevertheless, as Carr acknowledges, spotting later additions or expansions in these books, which are essentially Persian-era artifacts and which reflect the discourses of the early Second Temple era, is extremely difficult (cf. Carr, Formation, 188). 
I suggest that, by observing how such narratives construct memories via intertextual linkages within Yehudite discourse, one can begin to understand the intricacies of the social mnemonics of this ancient community. Social memory functioned systemically (as it always does), with various narratives contributing to feedback loops that informed Yehudite sociocultural and political identity. In this particular case, the evidence suggests that the society maintained and promulgated diverse (and even contradictory) memories of Yehud's distant and recent pasts, some hopeful and some not, and that it was able to do so on account of its diverse memories/images of the future. The remembered future - the construal of exile's end as new exodus, with all its diverse and discordant potentials - balanced the remembered past.

Social memory or remembering works as a »template that organizes and animates behavior and a frame within which people locate and find meaning for their present experience. ${ }^{10}$ Memories and the acts of remembering function as models of and models for society. ${ }^{11}$ In other words, communities look to certain socially shared memories because they see something there, in the construed past, that speaks to present concerns, and vice versa: present concerns help orient communities' understandings of their pasts. Or, as Jeffrey Olick puts it, social remembering »express[es] neither the past nor the present but the changing interactions between past and present: Past meanings are malleable to varying degrees and present circumstances exploit these potentials more or less. ${ }^{12}$ This is precisely what one finds in the discourse of exodus and exile in Yehudite literature. The conclusion to Kings, as Chan shows, evokes a memory of the conclusion to Genesis, which then points to the forthcoming exodus from Egypt as a template or frame for understanding Kings' view of exile and return. The literature, the ways by which it creates allusions and intertexts and guides remembering, represents and reflects the social mnemonics of the literary culture that produced and maintained it. ${ }^{13}$ The question then becomes: What exactly does this remembering

10 B. Schwartz, Abraham Lincoln and the Forge of National Memory, 2000, 18. Italics original. 11 Cf. Schwartz, Abraham Lincoln and the Forge; idem, Abraham Lincoln in the Post-Heroic Era, 2008. The concept of modeling comes from the cultural anthropology of C. Geertz (see The Interpretation of Cultures, 1973, 93-94).

12 J. K. Olick, The Politics of Regret, 2007, 55-56.

13 See R. Lachmann, Mnemonic and Intertextual Aspects of Literature, in: A. Erll/A. Nünning (eds.), with S. B. Young, A Companion to Cultural Memory Studies, 2010, 301-310; also F. Landy, Notes Towards a Poetics of Memory in Ancient Israel, in: E. Ben Zvi/C. Levin (eds.), Remembering 
tell us? What did it mean for the literati to read the end of Kings as mnemonically modeling the exodus?

First, I would like to take a step back and consider the discursive possibilities of II Reg 25,27-30. As I said above, I agree with Chan and others that this text alludes to the Joseph story, and that it was taking part in an Enneateuchal discourse as it were, which shifted hope away from the Judahite monarchy and Davidic kingship and toward the people itself, thus problematizing von Rad's idea that these verses were meant to renew faith in the Davidic dynasty going forward. ${ }^{14}$ There remained, nevertheless, a strong pro-David stance in the books of Samuel and Kings. ${ }^{15}$ To be sure, the so-called »Court History« or "Succession Narrative« (II Sam 9-20; I Reg 1-2) remembered David as a flawed and even tragic figure, but this did not override his status as the paragon of kingship to which all subsequent kings were to be compared (e.g., I Reg 11,4.6; 15,3-5.11; II Reg 14,3; 16,2; 18,3; 22,2; etc.). ${ }^{16}$ Indeed, remembering the Davidic promises and their ongoing import was a complicated affair. ${ }^{17}$ In II Sam 7 the promise appears to be unconditional: it speaks of establishing David's kingly house and its throne (כסא) forever (עד עולם), without asking anything of David in return (vv. 13-16; cf. II Sam 22,51; 23,5). Note, however, that within the same set of books Yahweh has already reneged on a promise that was meant to last »forever « (I Sam 2,30-34), and, when the Davidic promise is restated later to Solomon, it is conditional upon that king's following the deity's laws (I Reg 9,4-9). Moreover, when Solomon fails to do this and Yahweh divides the kingdom, the deity makes a similar promise to Jeroboam, a non-Davidide (I Reg 11,29-39), but in doing so the deity holds out the possibility that Davidic presence will remain in Jerusalem indefinitely (cf. vv. 32.36.39). So is David's line meant to last forever in Jerusalem or not? One finds the same tension

and Forgetting in Early Second Temple Judah, FAT 85, 2012, 331-345. One should not forget, of course, that literature and its discourses is only one aspect of social mnemonics. Remembering is a network of processes that involves the psychological and the social, the individual and the group, the physical world and its real and imagined landscapes (however understood), perceptions influenced by all of the human senses in a variety of milieux. See P. Boyer/J. V. Wertsch (eds.), Memory in Mind and Culture, 2009. The physical realities of Yehudite life, and how Yehudite literati understood and interpreted these realities vis-à-vis their remembered pasts, were another important aspect of that particular community's memory and remembering.

14 See Chan, Joseph, 575, and references there.

15 Which is one reason why many scholars argue that these books must have some roots in the Judahite monarchic era. Cf. T. Römer, The So-Called Deuteronomistic History, 2007, 67-72.

16 See J. Blenkinsopp, Another Contribution to the Succession Narrative Debate, JSOT 38 (2013), 35-58.

17 See G. Knoppers, David's Relation to Moses, in: J. Day (ed.), King and Messiah in Israel and the Ancient Near East, JSOTSup 270, 1998, 91-118. 
in the Psalms, in which Davidic kingship is either unconditional or conditional, either rejected outright or an eternal sign of future hope (e.g., Ps 18 [//II Sam 22]; 89; 132). Given these various and incongruent statements in the discourse, one must have recognized in II Reg 25,27-30 some paradoxical irony. The Davidic line remains, as promised, its representative sitting upon a throne (כסא) (v. 28). Yet the throne is in Babylon, not Jerusalem, he has been placed there by a foreign king, not by Yahweh, and the favor he receives lasts merely all the days of his life (v. 30), not »forever «. The text depicts the Davidic dynasty as something of a failure, but the dynasty is alive and well nonetheless. One can successfully argue, as Chan has, that the hopeful aspect of this text is its depiction of a prominent Judahite/ Israelite doing well in a foreign court, but the fact remains that this hope stands with a living descendent of David, at the conclusion to a lengthy narrative that highlights, in several key places, the import of Davidic kingship for Israel's past and future. There is, thus, a strong tension at the conclusion to Kings, one that reflects the tension throughout the discourse as a whole. ${ }^{18}$ Yehudites could have taken this text in several directions. Indeed, if the prophetic books are any indication, they did take the story in numerous directions, some of which emphasized return and/or a kind of Davidic hope, and some of which did not; ${ }^{19}$ and all this is to say nothing of Chronicles' perspective on Israel's Davidic past and future (more below). The point is, the conclusion to Kings may tend toward one perspective in the discourse, but it does not eliminate the memories or importance of other

18 This is precisely the tension F. M. Cross was trying to account for with his two-edition Deuteronomistic History, which attempted to explain the tragedy/judgment emphasized by Noth as well as the hope/grace emphasized by von Rad. Wolff had preceded Cross in suggesting an editorial balancing of judgment and grace (the latter attained via repentance), but Cross rightly argued that Wolff's analysis paid too little attention to the prominent theme of Davidic promise. See Cross, Canaanite Myth and Hebrew Epic, 1973, 274-289. Pace Chan, Joseph, 568, Cross's main point is not that II Reg 25,27-30 is the work of a "second- or third-rate Dtr " (Cross indeed calls this editor »less articulate« [Canaanite Myth, 288], but one should not overemphasize this aspect of Cross's argument, which is a minor point). Cross argues that a postmonarchic editor was trying to account for the tragedy of exile while simultaneously maintaining the central importance of the Davidic promise found in an original, monarchic-era version of the History. According to Cross, this explains the strange irony and tension one finds at the end of Kings. One does not have to agree with Cross's proposal concerning the compositional history of these books (or his assessment of the postmonarchic editor's lucidity) in order to appreciate the tension he emphasizes between Davidic promise and failure. As I emphasize above, the »forever «-ness of the Davidic promise is not as certain as Cross wanted it to be, but the promise is there nonetheless and one should not discount it as a major theme in Samuel and Kings.

19 Cf. R. E. Clements, A Royal Privilege (2 Kings 25.27-30), in: R. Rezetko/T. H. Lim/W. B. Aucker (eds.), Reflection and Refraction (Festschrift Auld), VTSup 113, 2007, 49-66. 
perspectives codified and read in a corpus of authoritative literature. Undermining the necessity of Davidic kingship at the end of Kings does not totally remove its prominence elsewhere in the literature (even in the same book), and thus does not completely eliminate its import for the Yehudite audience of these texts. If one focuses solely on Jehoiachin, then yes, »There is no hope to be found in the Judahite monarchy«; ${ }^{20}$ but as soon as one expands one's literary purview to include the entire Yehudite discourse on David and Davidic kingship, such a statement becomes problematic.

The conclusion to the book of Kings is, then, multivocal and even ironic, its import for and relationship to the larger story of Israel not so clearly stated. But so too is the ongoing exile and impending exodus, to which II Reg 25,27-30 alludes. Like remembering Davidic kingship, remembering exile and exodus is complicated. The exile/exodus, in Israel's story, symbolizes at once the people's oppression and its freedom, its failures and its successes, its struggle with apostasy and its devotion to Yahweh. Recall the beginning of the exodus story, just after the death of Joseph: the people multiply and prosper in the land of Egypt, but Egypt quickly forgets the greatness of Joseph; the next generation of Egyptian kingship takes the throne, and the Israelites lose their special status in the foreign land and become slaves (Ex 1,1-12).

This betrays a double meaning for the allusive bridge that stretches from Jehoiachin to Joseph. On the one hand, as Chan argues, it signified a hopeful time of prosperity in exile, reflected in the »Diaspora novels « of Esther, Daniel, and the like. ${ }^{21}$ On the other hand, however, it signified a time of oppression in a foreign land, which necessitated Yahweh's eventual intervention on the oppressed people's behalf. One only has to travel a short distance beyond the allusive bridge to reach the latter scenario. This latter narrative outcome, of course, also offered hope, but it was a delayed and attenuated hope. In the exodus narrative, freedom is attained only after a considerable amount of time spent under Egyptian subjugation, the exodus itself is an event fraught with difficulty and disaster, and the conquest of the promised land is not an unqualified success. Remembering exile/ exodus was, thus, double-edged. It could offer a kind of hope, via the narratives of a prosperous diaspora and via the concept of an »empty« and restored land to which the people can finally return (see esp. Chr and Ezr-Neh), ${ }^{22}$ but elsewhere the element of hope is less prominent. To be sure, one strand of thought clearly recognizes that - after disaster and destruction and a period of servanthood/

20 Chan, Joseph, 575.

21 Chan, Joseph, 569; cf. Römer, So-Called Deuteronomistic History, 2007, 177.

22 See Carroll, Exile!, 64-65. 
slavery to foreign rulers - there was a return to Jerusalem and a rebuilding of Yahweh's temple there (e.g., II Chr 36,9-23). And the temple was, after all, actually rebuilt. This transition back to Jerusalem, however, like the original exodus and eisodus, was also remembered as none too easy, and in some cases incomplete, that is, in some cases diaspora was thought to be not a good thing. ${ }^{23}$

The prophetic books in particular speak to this complexity in Yehudite social remembering. Take the book of Isaiah, for instance, which famously employs the tropes in a variety of ways, offering a variety of mnemonic keys for its Yehudite readership construing exile and exodus as part and parcel of Israel's past and present. Chan cites Isa 43,16-21; 51,9-10; and 52,7-12, which all allude to the exodus as a symbol of Yahweh's creative and salvific actions. ${ }^{24}$ One may add to these references, inter alia, Isa 10,5-12,6 and 63,7-14, which each contain allusions to and echoes of the exodus and specifically the Song of the Sea (Ex 15,1-21). ${ }^{25}$ These texts memorialize the victorious aspect of the exodus and the sea-crossing but also its liminality, its already-but-not-yet element that calls

23 One should also keep in mind that Egypt and Babylon are significantly different localities, each with its own complex signification in Yehudite literature. Exodus from one is not necessarily the same as return from the other. While Jehoiachin's exaltation in Babylon may signify a positive take on diaspora there, the contemporary diaspora in Egypt is, for the most part, not remembered positively (contra the memory of Joseph's time in Egypt). See Jer 24,8-10; 42,13-22; etc. (and note that Jeremiah ends up there anyway: Jer 43,4-7). Interestingly, the figure of Abraham seems to bring these two perspectives together in the discourse (and contributes much to our knowledge of the exodus/exile trope in general). See E. Ben Zvi, The Memory of Abraham in Late Persian/Early Hellenistic Yehud/Judah, in: D. Edelman/E. Ben Zvi (eds.), Remembering Biblical Figures in the Late Persian and Early Hellenistic Periods, 2013, 3-37, 27-30. Because Abraham is a figure that predates exodus/exile in Israel's remembered past, he can embody multiple aspects of the issue at once. He is a quasi-Israelite Mesopotamian who sojourns in the land of Canaan before it belongs to Israel, thus he is in a kind of »exile« in his future people's own land. He travels to Egypt where he meets hardships but also encounters prosperity. And his actions in the land are symbolically linked to Jerusalem, (Davidic) kingship, priesthood, and the temple (Gen 14,17-20; 22,2; cf. Ps 110; II Chr 3,1). See T. Römer, Abraham and the »Law and the Prophets«, in: P. Carstens/N. P. Lemche (eds.), The Reception and Remembrance of Abraham, PHSC 13, 2011, 87-101.

24 Chan, Joseph, 576. In addition to the works cited by Chan, see also U. Berges, Der zweite Exodus im Jesajabuch, in: F.-L. Hossfeld/L. Schwienhorst-Schönberger (eds.), Das Manna fällt auch heute noch (Festschrift Zenger), 2004, 77-95; K. Schmid, Neue Schöpfung als Überbietung des neuen Exodus, in: Schriftgelehrte Traditionsliteratur, FAT 77, 2011, 185-205; L.-S. Tiemeyer, For the Comfort of Zion, VTSup 139, 2011, 155-203.

25 See I. D. Wilson, The Song of the Sea and Isaiah, in: E. Ben Zvi/C. Levin (eds.), Thinking of Water in the Early Second Temple Period, BZAW 461, forthcoming 2014. 
to mind at once a sense of arrival and a sense of longing to arrive. ${ }^{26}$ Note especially Isa 63,7-14, which remembers exodus and sea at the outset of a passage that solemnly concludes: »After all this, will you hold yourself back, Yahweh? Will you remain silent and oppress us so very much? « (Isa 64,11). Contrast this with the hopefulness one finds in Isa 43,1-44,5, which is also laden with exodus imagery and memories; this passage, though it certainly recalls transgressions and difficulties, ultimately emphasizes Yahweh's redemption and recreation of his people. Naturally, one finds something similar in the book's interwoven and related remembering of exile. Exile stands for $\sin /$ redemption (e.g., Isa 40,1-2; 48,20-21), and also for death/new life (e.g., Isa 42,18-25; 51,12-16). ${ }^{27}$ Isaiah, and the corpus of prophetic books as a whole, knows of and memorializes an end to exile and a subsequent return, but it is also strongly aware of diaspora's continued existence. Thus, for some, from the perspective of these texts at least, redemption and new life had been achieved, while for others exile (and symbolically sin and death) continued. In effect, remembering exile with these texts was to remember in part that exile had not ended, and for some it never would. ${ }^{28}$ James Linville comments:

\begin{abstract}
What we have then, is really two competing mythologies .... One is of an eternal expulsion and death; the other is of the capacity to bring order and life once again to the cosmos. The two myths coexist within the ancient Judean symbolic universe. There is never a perfect resolution of their incipiently problematic tensions, just as we have with the multiple creation myths. Nor should we expect there to be. ${ }^{29}$
\end{abstract}

To be sure, pro-diaspora memories, such as what one finds in II Reg 25,27-30 and Gen 40-41, balanced the discourse, but they remained in tension with these memories of exile as punishment and even death.

26 The Song of the Sea, which mnemonically frames many of these passages in Isaiah, instills a sense of liminality in its readers via its shifting verbal aspect, which blurs the temporal and geographical context of its events. See Wilson, Song of the Sea.

27 See M. A. Halvorson-Taylor, Enduring Exile, VTSup141, 2011, 109-135.

28 See J. R. Linville, Myth of the Exilic Return, in: E. Ben Zvi/C. Levin (eds.), The Concept of Exile in Ancient Israel and its Historical Contexts, BZAW 404, 2010, 295-308. Cf. Carroll, Exile!, 65-67.78-79. Carroll rightly emphasizes that the concept of »exile« itself is necessarily a Jerusalem-centered idea. By claiming, however, that this ideology has »contaminated « the Hebrew Bible (Exile!, 79), he goes much farther than I would. Respectfully setting aside any and all contemporary theological and political issues concerning Jerusalem and diaspora, I would argue that this ideology simply reflects the primary milieu in which and for which these ancient books emerged as authoritative documents (i.e., early Second Temple-era Yehud).

29 Linville, Myth, 305-306. 
Another and related issue to consider is, as mentioned above, exodus/exile takes place over a protracted time period. If the allusive bridge to Joseph takes one down the path of remembering exodus, then a lot happens in the story before eisodus is realized (indeed, the entire narrative of Ex-Jos). There is wandering in the wilderness, judgment and purification, divine instruction for the people (cf. Ez 20). Thus, any future hope, that which lies beyond oppression and slavery in a foreign land (be it a restored kind of Davidic kingship or not), was to be accompanied by a prolonged coming-of-age process in which Israel must (re) receive and (re)learn Yahweh's Torah and (re)establish a holy abode for the deity in the promised land. This process is ultimately hopeful - one will eventually arrive at one's destination - but it is also difficult and at times tedious. Haggai and Zechariah, for example, evinced the remembered difficulties of return, which parallel the difficulties of exodus (in fact, all the prophetic books do in one way or another). Moreover, the fresh start as it were that exodus/exile provided also implied a reset of Israel's political foundations and structures. Exodus, the concept, necessarily recalled the prophetic-judicial-priestly (and even kingly) leadership of Moses in the wilderness, the similar leadership of Joshua during the conquest, and the related era of judgeship and eventually kingship in the land, as well as Torah's contributions to one's understandings of all these interrelated roles. ${ }^{30}$ Questions of officialdom and its standing vis-à-vis Israel's political and cultic institutions and practices would have come to the fore yet again. At the conclusion to this exodus, was judgeship to emerge anew (Ob 1.21)? Some kind of Davidide (Jer 23,5-6; Ez 37,24-25)? A »kingdom of priests « (Ex 19,5-6)? The Davidization of all Israel (Isa 55,3-5)? These are only a few of the potentials, of course. Remembering return as exodus (and exodus as return) meant remembering a lengthy and detailed past narrative, thus creating plenty of space in Yehudite social memory for these present and future potentials to play out and even stand in tension with one another in Yehudite thought.

Now, raising the potential for a Davidide or the Davidization of the people, we are right back where we started, wondering about the import of kingship and the Davidic promises for Yehud's/Israel's past, present, and future. Although II Reg 25,27-30 diminishes expectations for an actual, ongoing line of Davidic kings in Jerusalem, the discourse in which it takes part certainly emphasizes the importance of Davidic kingship, as a central concept, for Yehudite life and thought;

30 On Moses and Joshua, see the recent articles by T. Römer, Moses, the Royal Lawgiver; E. A. Knauf, Remembering Joshua; and E. Ben Zvi, Exploring the Memory of Moses `The Prophet in Late Persian/Early Hellenistic Yehud/Judah, in: Edelman/Ben Zvi, Remembering Biblical Figures, 81-94, 107-125, and 335-364, respectively. 
the main issue is thus not dynastic succession or lineage per se but the pervasiveness of the idea(s) of Davidic kingship in Yehudite literature and memory. ${ }^{31}$ With this in mind, I would like to make a few comments on the conclusion to Chronicles' historiography. Chronicles, instead of concluding with Jehoiachin's exaltation in Babylon, ends by making the exile a definite time period, a seventy-year sabbath for the land (II Chr 36,21; cf. Lev 26,3-45; Jer 29,10-14), and by recounting Cyrus's proclamation that Yahweh has charged him, king of Persia, to rebuild the temple in Jerusalem (II Chr 36,22-23; cf. Ezr 1,1-4). What is implicit at the end of Kings is explicit at the end of Chronicles: the people are to return to the land, to a hopeful future. In this case, though, the rebuilt temple is the future hope. Temple is, of course, a major Leitmotiv in Chronicles, and has strong links with Davidic kingship. ${ }^{32}$ In Chronicles, the temple is originally David's initiative (I Chr 17), which he passes on to his son Solomon (I Chr 28), and then Cyrus, via Yahweh's command, takes up the Davidic initiative again. ${ }^{33}$ The book of Isaiah, in addition, had something to say on this matter for Yehudites. There too Cyrus is temple-builder (Isa 44,24-28; cf. 45,13), and he is directly linked to David via theologically loaded titles given to him by Yahweh. ${ }^{34}$ Like David, he is Yahweh's shepherd (רעה) (Isa 44,28) and anointed (משיח) (Isa 45,1). By handing over these titles to Cyrus, the discourse also hands over all of the titles' theological implications. ${ }^{35}$ The discourse thus presents Cyrus as a quasi-Davidide, who »has taken the place of the Davidic royal house, at least for the time being $"{ }^{36}$ As a kind of Davidide who is nonetheless a foreigner and the »king of Persia«, Cyrus's »otherness is consistently blurred «, ${ }^{37}$ so remembering him challenged the boundaries

31 Cf. Knoppers, David's Relation, 117-118.

32 See M. J. Boda, Gazing though the Cloud of Incense, in: P. S. Evans/T. F. Williams (eds.), Chronicling the Chronicler, 2013, 215-245.

33 In general, Chronicles' idea of kingship is one of regency: i.e., human kingship in Israel is positioned underneath the universal and eternal reign of the deity; cf. H. G.M. Williamson, 1 and 2 Chronicles, NCBC, 1982, 26-27. Thus, Cyrus, his non-Israelite status notwithstanding, functions as ruler of Israel, filling the void left by the exiled Davidic line; cf. W. Riley, King and Cultus in Chronicles, JSOTSup 160, 1993, 178.193.

34 Cyrus is probably the key figure for Isa 40-48, and perhaps for the entire text of so-called Second Isaiah. See, inter alia, R. G. Kratz, Kyros im Deuterojesaja-Buch, FAT 1, 1991; J. Blenkinsopp, David Remembered: Kingship and National Identity in Ancient Israel, 2013, 64-70.

35 Cf. L. S. Fried, Cyrus the Messiah? The Historical Background of Isaiah 45:1, HTR 95 (2002), 373-393, 390. Pace Clements, Royal Privilege, 63.

36 J. Blenkinsopp, Isaiah 40-55, AB 19A, 2002, 249.

37 E. Ben Zvi, History, Literature and Theology in the Book of Chronicles, 2006, 279; cf. L. Jonker, 1 \& 2 Chronicles, 2013, 316-318. 
of Yehudite identity. ${ }^{38}$ The conclusions to Kings and Chronicles, then, speak to similar issues but formulate very different statements. At the end of Kings one finds an actual Davidide living in the court of Babylon, doing well but far from the Jerusalem throne, while in Chronicles one finds a Davidized foreigner reigning in Persia as Yahweh's chosen hero to restore Israel and its cult in the proper place of Jerusalem. One implicitly signals exodus, and all the hopes and disappointments that go along with it, whereas the other signals a very specific moment of eisodus, the return to Jerusalem for the purpose of rebuilding Yahweh's house there. Both historiographies, therefore, contributed to the remembering of exodus/exile in Yehud, and both stirred hope for those remembering, but each had its own takes on what actually constituted that hope, and how it played out in the rest of the narrative.

To conclude, I would like to make a preliminary suggestion concerning the Yehudite socio-mnemonic system, that is, how social remembering worked for the literati maintaining and reading and promulgating these books in the locality of early Second Temple-era Yehud. It has often been observed that societies tend to emphasize certain memories to the exclusion of others, creating a more balanced and focused picture of the past that better informs their present (and future) ${ }^{39} \mathrm{At}$ least in part, this is true for Yehudite social remembering too. ${ }^{40}$ In their remembering of exodus/exile (as event and/or concept) and the related issue of Davidic kingship (and Israelite sociopolitics in general), however, we observe something different. Yehudite literati produced, maintained, and promulgated a corpus of authoritative literature about their past (including the historiographies of SamReg and Chr) that conceived complex and sometimes very different ideas about exodus/exile and kingship as crucial aspects of that past. Likewise, the literature conceived a variety of ideas about how those crucial aspects of the past did and would lead into the community's present and future. As demonstrated above, the conclusions to Kings and Chronicles, two books that each garnered a certain

38 See I. D. Wilson, Yahweh's Anointed: Cyrus, Deuteronomy's Law of the King, and Yehudite Identity, forthcoming.

39 E.g., B. Schwartz, Collective Forgetting and the Symbolic Power of Oneness, Social Psychology Quarterly 72 (2009), 123-142.

40 Cf. E. Ben Zvi, The Study of Forgetting and the Forgotten in Ancient Israelite Discourses, in: P. Carstens/T. Hasselbach/N. P. Lemche (eds.), Cultural Memory in Biblical Exegesis, PHSC 17, 2012, 155-174. 
amount of authority for Yehudites, ${ }^{41}$ remember similar issues but handle them in different ways, and the prophetic books also take part in the discourse, supporting and challenging the various claims of the historiographical texts concerning the community's past and its self-understandings for the present and future. There was no single way to remember and understand exodus/exile or kingship in Yehud. How do we account for this multivocality in Yehudite social remembering, and what does this tell us about its culture? I submit, simply, if Yehud's model of society (its remembered past) was multivocal, then its model for society (its remembered present and future) required multivocality as well. As the historiographical literature emerged in its authoritative forms (including the books of Gen-Reg, Chr, etc.), it found a mutually reinforcing partnership as it were with the prophetic literature. ${ }^{42}$ The multivocal remembered future balanced the multivocal remembered past, and vice versa. This observation, seemingly simple as it may be, has potentially significant and unexplored implications for our understandings of historiographical and prophetic texts, their interrelationship, and their generic and sociocultural functions, in Yehud in the early Second Temple era.

Abstract: In a recent ZAW article, Michael Chan argues that II Reg 25,27-30 alludes to Gen 40-41, and that this allusion provides a hermeneutical key for understanding the purpose of II Reg 25,27-30 in an Enneateuchal context: it points to an imminent exodus, a return from exile and a gathering of diaspora in the promised land. This article picks up where Chan left off, in order to flesh out some of the implications of his contribution. It argues that remembering exodus at the end of II Reg included hope, as Chan says, but also struggles and failure, punishment and death. Exodus is multivocal. Likewise, the end of II Reg contributes to a multivocal discourse concerning Davidic kingship, which included the end of Chronicles and prophetic literature. The diminution of Davidic kingship in II Reg 25,27-30 is balanced by other perspectives. The article concludes with an observation on the import of this multivocality for Yehudite social memory.

Résumé: Dans un article récent de la ZAW, Michael Chan tente d'établir que II Rois 25,27-30 fait allusion à Gen. 40-41, et que cette relation offre une clé herméneutique pour la compréhension de cette péricope dans le contexte de l'Ennéa-

41 Kings was the more authoritative of the two, but Yehudites clearly also read Chronicles and considered it to be authoritative in some way, as later Second Temple-era literature evinces. Cf. G. Knoppers, I Chronicles 1-9, AB 12, 2003, 105-111.

42 Cf. Schmid, Old Testament, 161. 
teuque: celle-ci renvoie à un exode imminent, un retour de l'exil et un rassemblement de la diaspora en terre promise. Cette étude prend le relais de celle de Chan, afin d'élucider certaines implications de sa contribution. L'A. soutient que l'évocation de l'Exode à la fin de II Rois inclut l'espérance (comme Chan le dit), mais aussi les combats et les échecs, la punition et la mort. L'exode est polysémique. De la même manière, la fin de II Rois contribue à un discours polyvalent sur la royauté de David, auquel participent aussi la fin des Chroniques et la littérature prophétique. L'amoindrissement de la royauté davidique en II Rois 25,27-30 est compensé par d'autres perspectives. On note enfin l'importance de cette polysémie pour la mémoire collective de Juda.

Zusammenfassung: In einem aktuellen ZAW-Aufsatz argumentiert Michael Chan, dass II Reg 25,27-30 auf Gen 40-41 anspielt, und dass diese Anspielung einen hermeneutischen Schlüssel für das Verständnis von II Reg 25,27-30 im Kontext des Enneateuch bereitstellt: Diese verweist auf einen nahe bevorstehenden Exodus, eine Rückkehr aus dem Exil und eine Sammlung der Diaspora im verheißenen Land. Dieser Artikel beginnt dort, wo Chan aufgehört hat, um einige der Konsequenzen seines Beitrags zu verdeutlichen. Es wird argumentiert, dass die Erinnerung an den Exodus am Ende von II Reg Hoffnung einschließt, wie Chan sagt, aber auch Kämpfe und Scheitern, Strafe und Tod. Der Exodus ist mehrdeutig. In ähnlicher Weise trägt das Ende von II Reg zu einem vielstimmigen Diskurs über das davidische Königtum bei, zu dem auch das Ende der Chronik und die prophetische Literatur gehören. Die Verkleinerung des davidischen Königtums in II Reg 25,27-30 wird durch andere Perspektiven ausbalanciert. Der Artikel schließt mit einer Beobachtung über die Bedeutung dieser Vielstimmigkeit für das kollektive Gedächtnis Jehuds. 